Between Europe and America 
Also by Andrew Gamble

THE FREE ECONOMY AND THE STRONG STATE: The Politics of Thatcherism HAYEK: The Iron Cage of Liberty

POLITICS AND FATE

THE CONSERVATIVE NATION

BRITAIN IN DECLINE: Economic Policy, Political Strategy and the British State 


\section{Between Europe and America}

\section{The Future of British Politics}

Andrew Gamble 


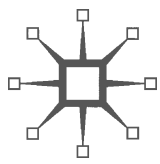

(c) Andrew Gamble 2003

All rights reserved. No reproduction, copy or transmission of this publication may be made without written permission.

No paragraph of this publication may be reproduced, copied or transmitted save with written permission or in accordance with the provisions of the Copyright, Designs and Patents Act 1988, or under the terms of any licence permitting limited copying issued by the Copyright Licensing Agency, 90 Tottenham Court Road, London W1T 4LP.

Any person who does any unauthorized act in relation to this publication may be liable to criminal prosecution and civil claims for damages.

The author has asserted his right to be identified as the author of this work in accordance with the Copyright, Designs and Patents Act 1988

First published 2003 by PALGRAVE MACMILLAN

Houndmills, Basingstoke, Hampshire RG21 6XS and

175 Fifth Avenue, New York, N.Y. 10010

Companies and representatives throughout the world

PALGRAVE MACMILLAN is the global academic imprint of the Palgrave Macmillan division of St. Martin's Press, LLC and of Palgrave Macmillan Ltd. Macmillan ${ }^{\circledR}$ is a registered trademark in the United States, United Kingdom and other countries. Palgrave is a registered trademark in the European Union and other countries.

ISBN 978-0-333-55570-5 hardback

ISBN 978-0-333-55571-2

ISBN 978-1-4039-4045-2 (eBook)

DOI 10.1007/978-1-4039-4045-2

This book is printed on paper suitable for recycling and made from fully managed and sustained forest sources.

A catalogue record for this book is available from the British Library.

Library of Congress Cataloging-in-Publication Data

Gamble, Andrew.

Between Europe and America : the future of British politics/

Andrew Gamble.

p. $\mathrm{cm}$.

Includes bibliographical references and index.

ISBN 978-0-333-55570-5 (hardback)-ISBN 978-0-333-55571-2 (pbk.)

1. Great Britain-Politics and government-1997-2. Great Britian-

Politics and government. 3. Great Britain-Civilization-American influences.

4. Great Britain-Civilization-European influences. I. Title.

JN231.G34 2003

324'.0941-dc21

$\begin{array}{llllllllll}10 & 9 & 8 & 7 & 6 & 5 & 4 & 3 & 2 & 1\end{array}$

$\begin{array}{llllllllll}12 & 11 & 10 & 09 & 08 & 07 & 06 & 05 & 04 & 03\end{array}$

Typeset by Cambrian Typesetters, Frimley, Camberley, Surrey 
For my parents 


\section{Contents}

Preface

ix

1 English Questions 1

British Politics and Decline 5

Identity and Political Economy 9

The English Model $\quad 12$

Left and Right 14

Plan of the Book $\quad 15$

2 The World Island 17

England and Britain $\quad 18$

The Constitutional Question $\quad 22$

Decline 25

The Four Circles of England $\quad 30$

England as a World Island 34

3 State of the Union 40

The Construction of Britishness $\quad 42$

Empire and Socialism 48

Ireland $\quad 52$

Devolution and Self-government 56

4 The Empire Within 61

Race and Empire $\quad 62$

The Expansion of England $\quad 68$

Patriotism and Empire $\quad 73$

The State and the Empire $\quad 76$

The Political Economy of Empire 77

5 Anglo-America $\quad 83$

The Meaning of Anglo-America $\quad 86$

The Rise of Global Hegemony $\quad 89$

$\begin{array}{lr}\text { The Special Relationship } & 97\end{array}$

The Anglo-American Model of Capitalism 102

6 The Reluctant Europeans 108

English or European? 109

The European Question 113 
European Cooperation after $1945 \quad 115$

Entry to the European Community 116

Early Membership 118

Ever Closer Union $\quad 122$

Political Economy 125

7 The English Model 132

English Capitalism 134

Critics of English Capitalism 141

The English Constitution 146

Critics of the English Constitution $\quad 150$

British socialism 154

Critics of British Socialism 157

Conclusion 159

8 Conservative Schisms $\quad 161$

The Conservative Century 162

Conservative Political Hegemony 164

$\begin{array}{ll}\text { Thatcherism } & 170\end{array}$

The Unionists' Last Stand $\quad 171$

Empire, Anglo-America and Europe 174

Capitalism and Decline $\quad 179$

Self-government and Public Service 183

Welfare to Workfare $\quad 186$

$\begin{array}{ll}\text { Conclusion } & 187\end{array}$

9 Labour Old and New 189

New Labour $\quad 191$

Social Democracy and Democratic Socialism 195

Class and Progress 202

Union and Empire 206

Anglo-America and Europe $\quad 210$

Labour and the English Model 213

10 The Future of British Politics 219

After Empire $\quad 220$

After Decline 225

Notes and References 233

$\begin{array}{ll}\text { Index } & 259\end{array}$ 


\section{Preface}

This book is in part a development of earlier books I have written on British politics, particularly The Conservative Nation, Britain in Decline, and The Free Economy and the Strong State, but it also attempts something new. I began working on it at the time of the first Iraq war, and have finished it shortly after the beginning of the second. Many things happened in the interval to distract me from completing it, and there have been some big changes in British politics to take into account. In the course of the last decade or so it has had many different names, and has become a very different book from the one that was envisaged at the outset. Thanks are due to my publisher, Steven Kennedy, for being so patient, and supporting the project through to completion.

I have benefited greatly from discussions over the years with many friends, colleagues and students. This book would not have been possible without them.

ANDREW GAMBLE 